\title{
All That Is Solid Falls from the Sky: Modernity and the Volume of World Literature
}

\author{
Dominic Davies (D) \\ City, University of London, London, UK \\ Email: dominic.davies@city.ac.uk
}

\begin{abstract}
This article pits two conceptions of modernity-that of the Marxist humanist Marshall Berman and the ANT (Actor-Network Theory) sociologist Bruno Latour-against each other, exploring the implications of each for postcolonial and world literary criticism. The article begins by explaining "modernity" in the terms of both theorists, focusing on the "split" between subject and object, text and world. It then identifies a wider Latourian turn in postcolonial and world literary studies that has emerged in response to the prescriptively structural approaches of groups such as the WReC. In response, the article offers in turn a Latourian reading and then a structural critique of the Colombian novelist Juan Gabriel Vásquez's fifth novel, The Sound of Things Falling (2011, trans. 2013), probing their possibilities and limitations. In conclusion, it suggests Berman's more expansive definition of modernist practice as one way in which postcolonial and world literary criticism might more effectively mediate between structural critique and close reading.
\end{abstract}

Keywords: Marshall Berman; Bruno Latour; Juan Gabriel Vásquez; The Sound of Things Falling; modernity; world literature; Colombia; narcotics

\section{Introduction: All That Is Solid ...}

The Marxist writer and critic Marshall Berman devotes the entire first chapter of his pathbreaking study, All That Is Solid Melts into Air (1982), to a close reading of Goethe's Faust. The play is the German philosopher's life work: he began writing it in 1770, when he was only twenty-one, and returned to it throughout his life until its eventual publication in 1831, the year before his death. As Berman points out, the play therefore maps both Goethe's personal and intellectual development and the larger movement of Western society as it progressed through the industrial revolution. Indeed, for Berman it is exactly these two separate spheres-self-development and economic development, the artwork and society, literature and the world-that Goethe's antihero, Faust, 
determines to "fuse into one." ${ }^{1}$ At the beginning of the play, Faust ponders "in an intellectual's lonely room, in an abstracted and isolated realm of thought"; jump forward five acts and he commands "a far-reaching realm of production and exchange" created by the power of thought (and "a plentiful supply of labourers" too). ${ }^{2}$ It is precisely by wielding the power of abstraction that Faust creates a new material world: with the help of Mephistopheles, his youthful visions are no longer limited to "dreams, fantasies, or even theories," taking by the plays' conclusion the form of surprisingly "concrete programs, operational plans for transforming earth and sea." ${ }^{3}$ Faust becomes particularly obsessed with digging a "great drainage canal," part of a vast program of public works that reshapes the natural landscape into a "theatre of modernity"-in a later chapter, Berman will describe the US real estate magnate Robert Moses, notorious for his aggressive redevelopment of New York's infrastructure, as the twentieth-century Faust. ${ }^{4}$ As Berman writes, by the play's conclusion Faust has become godlike, a maker of societies and economies, an author of his own destiny and of the material world: "Standing on an artificial hill created by human labor, he overlooks the whole new world that he has brought into being, and it looks good." 5

In Faust, Goethe therefore dramatizes the split between abstract and material planes that, for Berman, is modernity's defining feature:

Our vision of modern life tends to split into material and spiritual planes: some people devote themselves to "modernism," which they see as a species of pure spirit, evolving in accord with its autonomous artistic and intellectual imperatives; other people work within the orbit of "modernization," a complex of material structures and processes-political, economic, socialwhich, supposedly, once it has got under way, runs on its own momentum with little or no input from human minds or souls. This dualism, pervasive in contemporary culture, cuts us all off from one of the pervasive facts of modern life: the interfusion of its material and spiritual forces, the intimate unity of the modern self and the modern environment. ${ }^{6}$

As a materialist committed to the spiritual value of literature and art, Berman's aim in All That Is Solid turns out to be remarkably similar to that of Goethe's Faust: he wishes to reunite the "material and spiritual planes" because it is through their continued separation that modernity disorients us, melting all that is solid

\footnotetext{
${ }^{1}$ Marshall Berman, All That Is Solid Melts into Air: The Experience of Modernity ([1982]; London: Penguin Books, 1988), 39-40.

${ }^{2}$ Berman, All That Is Solid Melts into Air, 39; see also Johann Wolfgang von Goethe, Faust I \& II, ed. and trans. by Stuart Atkins (Princeton, NJ, and Oxford: Princeton University Press, 1994), 291 (Act V, Line 11,554).

${ }^{3}$ Berman, All That Is Solid Melts into Air, 39.

${ }^{4}$ See Albert Schöne, "Faust-today," Goethe's Faust: Theatre of Modernity, eds. Hans Schulte, John Noyes, and Pia Kleber (Cambridge: Cambridge University Press, 2011), 17-31, esp. 20; Berman, All That Is Solid, 287-348.

${ }_{6}^{5}$ Berman, All That Is Solid Melts into Air, 65.

${ }^{6}$ Berman, All That Is Solid Melts into Air, 131-32.
} 
into air, and rendering us and our environments vulnerable to exploitation by the forces of capital. It is only by reconnecting these two spheres-"the concrete realism of the construction site" with "the symbolist ambience of Faust's inner world"-that, Berman argues, we might become modernists: "To be a modernist is to make oneself somehow at home in the maelstrom, to make its rhythms one's own, to move within its currents in search of the forms of reality, of beauty, of freedom, of justice, that its fervid and perilous flow allows." To be a modernist therefore is to accept the split between literature and the material world before using the one to make better sense of the other.

In this effort to rediscover the material, world-making power of abstract thought, Faust and Berman each hope to bridge what the French sociologist Bruno Latour has, with his customary provocation, called the "Great Divide": the foundational split that marks the birth of modernity. ${ }^{8}$ For Latour, this split is multifold and enabling, cleaving society from nature, abstract concepts from material actions, words from worlds, and objects from subjects. However, while Latour recognizes that this split has made possible several conceptual and material breakthroughs (canals and other public works projects among them), he also regards it as a fabrication and, ultimately, a mistake. Writing in what is perhaps his most notorious book, We Have Never Been Modern (1991), Latour argues that Immanuel Kant's Copernican Revolution sharpened "into a total separation" the already distinct Cartesian realms of an inside and an outside, thus deepening the separation of abstract thought from material action, and splintering writing from the world. For Latour, the legacy of Kant's Enlightenment thought has been to leave two poles between which countless modern thinkers-from Goethe right through to Berman and beyond-have sought to mediate ever since. ${ }^{9}$ Indeed, I begin this article with Berman's close reading of Goethe because it is precisely this same Faustian split that persists in debates about world literature today, wherein the task of developing increasingly elaborate theoretical frameworks to account for the relationship between literature and "the world" (or "worlds," or the "world-system," and so on) would be viewed by Latour as a typically modern-and on the whole misleading-endeavor.

For as his provocative title, We Have Never Been Modern, suggests, Latour believes that the so-called "split" that defines modernity is in fact a fabrication and a fiction-a fiction not without some incredibly enabling uses, to be sure, but still a social construction ungrounded in empirical reality. According to Latour, the world is not composed of subjects and objects, signs and signifieds, humans and nonhumans, as "the moderns" would have us believe; rather, we live in a universe of "quasi-objects," where the material world is always utterly enmeshed with the social and where the social always has material force. ${ }^{10}$ For example, in the part of his argument that will perhaps be most familiar to literary critics, Latour expresses an especially vicious distaste for a structuralist

\footnotetext{
${ }^{7}$ Berman, All That Is Solid Melts into Air, 345-46.

8 Bruno Latour, We Have Never Been Modern, trans. Catherine Porter (Cambridge, MA: Harvard University Press, 1993).

${ }^{9}$ Latour, We Have Never Been Modern, 56.

${ }^{10}$ Latour, We Have Never Been Modern, 51-55.
} 
approach to language that views words as little more than an "Empire of Signs"he mockingly quotes Roland Barthes-somehow entirely separated from the "real" world they are said to represent. ${ }^{11}$ For Latour, these so-called "signs" are themselves actors alive in the world, and the post-structuralist or postmodern detachment of the representation from the represented is little more than another iteration of the same false Kantian split that preoccupies Goethe's Faust.

Where Latour gets particularly interesting, however, is in his disavowal of materialist criticism. While materialists since Fredric Jameson have sought to close the (post-)structuralist gap by devising ways of reading the "real" world symptomatically in literary texts, Latour argues-in anticipation of his later contribution to the post-critical turn-that such methodologies in fact only bring the separation between literature and the world "even more fully to life." 12 Against both positions, Latour calls instead for an entirely new "CounterRevolution" against Kant's conceptual separation, one that rejects the original "sin," or "fall," of modernity's divisive split outright. ${ }^{13}$ Importantly, this is not an antimodern stance, which is actually more like Berman's modernist position and would first acknowledge and only then seek to undo the split between word and world. Rather, Latour presents a nonmodern metaphysics, or an "object-oriented ontology," in which there are no a priori structures or "worlds" as such, but instead only individual actors becoming more or less "real" through their direct alliances with others. ${ }^{14}$ From this perspective, literature and the world were never separate at all, an extremely tantalizing prospect for scholars of postcolonial and world literature who have long sought to reconnect the two.

By claiming that the divide between society and nature, and text and world, never actually existed, Latour opens up what he calls the "black box" of modernity. Latour uses this term, black box, to describe concepts or statements that are treated as incontrovertible facts, but which at one point in their history required careful experimentation, contestation, and argumentation in order to become accepted as such. ${ }^{15}$ The notion of modernity, for example, though

\footnotetext{
${ }^{11}$ Latour, We Have Never Been Modern, 63.

${ }^{12}$ Latour, We Have Never Been Modern, 57, my emphasis. See also Fredric Jameson, The Political Unconscious: Narrative as a Socially Symbolic Act (London: Routledge, 1983), and for a good overview of the post-critical turn, Elizabeth S. Anker and Rita Felski, eds., Critique and Postcritique (Durham, NC, and London: Duke University Press, 2017). Several contributors to that collection remain committed to the value of critique and wish only to loosen its dogmatic practice, an approach for which I have much sympathy.

${ }^{13}$ Latour's rhetoric, which is renowned for its playful-for some, disrespectful-defiance of academic convention, is littered with quasi-biblical metaphors of height, skies, falling, and weight. Take, for instance, his explanation of his theory of equal "actants" in We Have Never Been Modern: "At the beginning of the weighing-in process, a nuclear power plant, or a hole in the ozone layer, or a map of the human genome, or a rubber-tired metro train, or a satellite network, or a cluster of galaxies, weighs no more than a wood fire, or the sky that may fall on our heads, or a genealogy, or a cart, or spirits visible in the heavens, or a cosmogony." Latour, We Have Never Been Modern, 108. As we will see in more detail in the following, this object-oriented language and metaphoric cluster is designed to have physical as well as metaphysical import.

${ }^{14}$ Latour, We Have Never Been Modern, 47-48.

${ }^{15}$ Latour gives the example of the chemical composition of water as a "black box" concept, one that is today used without question as a building block in chemistry laboratories: "Who refers to
} 
accepted by Marxist humanists such as Berman as just such an incontrovertible fact, was after all hammered out by Kant, Goethe, and other Enlightenment thinkers at the end of the eighteenth and beginning of the nineteenth centuries. The irreverent rejection of modernity allows Latour to devise an entirely new, object-oriented metaphysical universe, a world in which mutually interacting "actants"-both human and nonhuman-"make the world" by forming alliances with other actors in networks. It is this model that underpins Latour's wellknown Actor-Network Theory, or ANT, and it has also provided a crucially important conceptual cornerstone for the posthumanities, where agency is ascribed not only to humans, but also to nonhuman "things"-animals, the climate, objects, and so on. ${ }^{16}$ Perhaps unsurprisingly, Latour's work is therefore now widely viewed as controversial, conspiratorial, and by many, politically radical: as Graham Harman writes, "Latour is the Galileo of metaphysics, ridiculing the split between the supralunar world of hard scientific fact and the sublunar world of human power games." 17

For this article's purposes, it is important to note that Latour's seemingly radical position also has some ostensible affinities with the anti-Enlightenment tradition long central to postcolonial studies, a body of thought that has in turn driven critiques of world literature's eurocentrism. ${ }^{18}$ However, while Latour certainly has something to teach scholars of both postcolonial and world literature, in this article I argue that it is a mistake to equate his anti-Enlightenment philosophy with the more specifically anticolonial critique of postcolonial studies. My aim here is to demonstrate both the extent and consequences of this mistake through a close reading of the Colombian novelist Juan Gabriel Vásquez's The Sound of Things Falling (Spanish 2011, English trans. 2013). This novel, which self-consciously and somewhat satirically builds its diegetic world with several of Latour's concepts, shares both thematic and formal interests with many other postcolonial and world literary texts: innovative narrative structures, repeated border crossings, blurred boundaries between private and public histories, a reflexive interest in representation and translatability, and so on. While my reading is therefore attentive to the novel, I intend its findings as a response to a wider Latourian turn in postcolonial and world literary studies, where Latour's work is increasingly used-both explicitly and implicitly-to

Lavoisier's paper when writing the formula $\mathrm{H}_{2} \mathrm{O}$ for water?" See Bruno Latour, Science in Action: How to Follow Scientists and Engineers Through Society (Cambridge, MA: Harvard University Press, 1987), 43.

${ }^{16}$ See Bruno Latour, Reassembling the Social: An Introduction to Actor-Network Theory (Oxford: Oxford University Press, 2005). For a discussion of both the implications and limitations of Latour's influence on posthumanist thinking, see Rosi Braidotti, The Posthuman (Cambridge: Polity Press, 2013), and for Braidotti's explanation of why she prefers Donna Haraway's work to Latour's as a foundation for her own posthumanist work, see Donna Haraway, "Posthuman, All Too Human: Towards a New Process Ontology," Theory, Culture, \& Society 23.7-8 (2006): 197-208.

${ }^{17}$ Graham Harman, Prince of Networks: Bruno Latour and Metaphysics (Melbourne: re.press, 2009), 59.

${ }^{18}$ See, for example, Aamir Mufti, "Orientalism and the Institution of World Literature," Critical Inquiry 36.3 (2010): 458-93; Graham Huggan, "The Trouble with World Literature," A Companion to Comparative Literature, eds. Ali Behdad and Dominic Thomas (Oxford: Wiley-Blackwell, 2011), 490"506; Robert Young, "World Literature and Postcolonialism," The Routledge Companion to World Literature, eds. Theo D'haen, David Damrosch, and Djelal Kadir (London: Routledge, 2014), 213-22. 
navigate the gap between the literary text and the world. ${ }^{19}$ In conclusion, having demonstrated through my reading both the possible benefits but also the dangerous limitations of Latour's work, I return to Berman's Faustian modernism because I believe it is there that we might find a better way to recognize world literature's "solidity," or "volume," without letting go-as Latour would have us do-of imperial and capitalist modernity altogether.

\section{World Literature's "Great Divide"}

Before proceeding with this close reading, it is first necessary to recognize that the Kantian split identified by both Latour and Berman-though each in their own way-is also the dilemma and founding premise of world literature and an ongoing preoccupation of postcolonial studies. Operating, like Berman, under the influence of Goethe, world literature by its own admission seeks to describe "the interaction of literature with its environment" and, in that way, reconnect the two: under Latour's microscope, it is therefore a typically modern project. As Alexander Beecroft remarks of the work of Damrosch, Casanova, and Moretti in the opening pages of An Ecology of World Literature (2016): "All of these, it seems to me, are not so much competing models for understanding how literature circulates, but rather different concrete answers, emerging in specific contexts, to the same set of problems about the interactions between literatures and their environments." 20 of course, the "world" in world literature can mean many different things: an autonomous marketplace, a smooth space of liberal-cosmopolitan exchange, a heterogeneous and uneven system, the capitalist worldsystem, a normative temporal horizon, and so on. But when world literature's raison d'être is understood as the attempt to repair the division between its two keywords, howsoever defined, these extraordinarily divergent and sometimes oppositional theories can be seen to have territory in common. ${ }^{21}$

\footnotetext{
${ }^{19}$ Latour has been creeping into postcolonial and world literary studies for a while now, primarily through environmental criticism. For example, he crops up once in Graham Huggan and Helen Tiffin, Postcolonial Ecocriticism: Literature, Animals, Environment (London and New York: Routledge, 2010), a few more times in Graham Huggan, ed., The Oxford Handbook of Postcolonial Studies (Oxford: Oxford University Press, 2013), and then even more influentially in Dipesh Chakrabarty, "Postcolonial Studies and the Challenge of Climate Change," New Literary History 43.1 (2012), 1-18, and Dipesh Chakrabarty, "Humanities in the Anthropocene: The Crisis of an Enduring Kantian Fable," New Literary History 47.2-3 (2016): 377-97. Latour's particular arguments about modernity have been less quickly absorbed, though they are mentioned briefly in Ania Loomba et al., eds., Postcolonial Studies and Beyond (Durham, NC, and London: Duke University Press, 2005). Latour has been cited only once in the Cambridge Journal of Postcolonial Literary Inquiry. By contrast, Latour's uptake in literary studies more generally has been astonishing. In New Literary History, for example, he has amassed citations in what I count to be more than eighty papers, and at the time of writing has himself published there three times, once in response to Rita Felski's special issue specifically devoted to the influence of his work: Recomposing the Humanities-with Bruno Latour 47.2-3 (2016).

${ }^{20}$ Alexander Beecroft, An Ecology of World Literature: From Antiquity to the Present Day (London and New York: Verso, 2015), 3.

${ }^{21}$ Even Pheng Cheah, who radically reorients the "world" from a spatial to a temporal designation, and thus seemingly upsets this polar equation, still reiterates this underlying division when he claims
} 
In her recent book, Postcolonialism After World Literature (2019), Lorna Burns goes to remarkable lengths to show how this Kantian division between "a representational realm and that of real-world action" not only pervades dominant theories of world literature but also haunts the "intractable debate between poststructuralism and Marxist historical materialism" that has long preoccupied postcolonial studies. ${ }^{22}$ In this dualism, the literary text can only ever be either a composite of spiraling signs without signifieds, or a mere reflection, representation, or registration of an a priori structure-those relentless "re"s always setting the text back from the world. Burns is particularly interested in the limitations of the Warwick Research Collective's theory of "world-literature" as a combined and uneven system, which she sees-quite rightly, I think-as extending this same debate from postcolonial studies through into world literary studies as well. In particular, she critiques the WReC for their persistent emphasis on the "failures" or "omissions" of literary texts, drawing on the work of Latour, Rita Felski, and the influential post-critical agenda that has flourished in their wake to support her argument. ${ }^{23}$ Lining up behind her a series of writers-Djelal Kadir, Timothy Bewes, Vilashini Cooppan-all interested in the "act" of critical reading, Burns then develops a Latourian sociology of world literature in which the literary text itself negotiates "the divide between representation and reality," that way becoming an "active participant in the creation of the social, and indeed, the world." ${ }^{24}$ As she concludes: "It is only by understanding the literary text as a world in which forces both active and reactive are operative that world literature and postcolonial studies alike can overcome the poststructuralist-materialist impasse and be reframed as critical projects that engage in the productive, revisionary and dissident capacity of all works of literature." 25

that literature "is infrastructural to reality," or "ontologically infrastructural to the existing world because the existing world's solidity is constituted by the giving of time." See Pheng Cheah, What Is a World? On Postcolonial Literature as World Literature (Durham, NC, and London: Duke University Press, 2016), 153, 311, my emphasis. Cheah spends much of his book mending a metaphysical division between literature and world, and as Latour would no doubt remark, it is in this effort that he proves himself to be especially "modern"; in Latour's metaphysical world, meanwhile, there "is no final infrastructure of reality that reduces the rest to mere ideological superstructure." See Harman, Prince of Networks, 72.

${ }^{22}$ Lorna Burns, Postcolonialism After World Literature: Relation, Equality, Dissent (London: Bloomsbury, 2019), 6. Theoretical and critical discussions about the relationship between literature and the world (or worlds) have always been especially fraught for scholars at the postcolonial end of the world literature spectrum. This is because of the explicitly political stakes that postcolonial scholars have always placed on literary texts (sometimes rightly, other times unfairly) and their insistence "that writing entails a form of activism." See Elleke Boehmer, Postcolonial Poetics: 21st Century Critical Readings (Palgrave MacMillan, 2018), 39.

${ }^{23}$ Burns, Postcolonialism After World Literature, 9. See also Bruno Latour, "Why Has Critique Run out of Steam? From Matters of Fact to Matters of Concern," Critical Inquiry 30 (Winter 2004): 225-48; Rita Felski, The Limits of Critique (Chicago, IL: University of Chicago Press, 2015); and Warwick Research Collective (WReC), Combined and Uneven Development: Towards a New Theory of World Literature (Liverpool: Liverpool University Press, 2015).

${ }^{24}$ Burns, Poscolonialism After World Literature, 120.

${ }^{25}$ Burns, Poscolonialism After World Literature, 120. 
In this project, Burns shares much with Elleke Boehmer's Postcolonial Poetics (2018), a study similarly influenced by the post-critical turn. ${ }^{26}$ Throughout her study, Boehmer places an "emphasis on doing" and "on interpretation over representation," construing the postcolonial writer, critic, and again, the text itself, as actors working together in a network. As she writes: "The poem (or other literary text of work) itself is where the meanings circulate," and the reader "works mentally, emotionally, and sometimes physically with it." ${ }^{27}$ Focusing on the poetics of the text, Boehmer implicitly seeks to escape the same Kantian split that Burns more explicitly outlines in her detailed engagement with Latour. Interestingly, Boehmer finds her way to an emphasis on sound, when she describes postcolonial poetics "as a score, as in music or dance, [positioning] the reader as the interpreter of that score, even as its performer." ${ }^{28}$ For Boehmer, the sound of postcolonial poetics bridges abstract representation and concrete reality, an intuition noted by Kant himself-the progenitor of modernity's divide -in his Anthropology from a Pragmatic Point of View (1798). As he writes there: "Because sounds are nothing in themselves or at any rate not objects, but merely signs of inner feelings, they are the best means of expressing concepts." ${ }^{29}$ This emphasis on sound therefore gives away the nonmodern designs of Boehmer's work, which though not explicitly acknowledged still seeks to disavow the Faustian division between abstract concepts and the material world.

To be clear, I share both Boehmer's and Burns's concern with the limits of the WReC's mode of critique, which I agree risks closing down the creative, dissident potential of literary texts. In their typically modern attempt to close the gap between literature and the world (their hyphenated "world-literature" leaves the smallest of scars), the WReC focus so dogmatically on the uneven worldsystem as it is registered within texts that their possibly resistant or reparative aspects are occluded or overlooked. This is one reason why, in my own practice below, I emphasize the value of close reading a literary text as a way to discover and test out a critical agenda, rather than shoe-horning that text into a prescribed, a priori framework. Indeed, by running with Burns and unpacking the implications of a Latourian reading of a world literary text, my aim is to probe not only what that methodology opens up, but also what it closes down. For as I will argue, when it comes to Latour, I think we have to go there to come back, so to speak. On the one hand, his work allows the literary text a welcome dose of solidity that the WReC's model of world literature refuses. On the other, however, I also fear that Latour's philosophy is too good to be true, concurring with his critics that ANT has proven so popular among academics from various disciplines in recent years precisely because it captures "the imagination of

\footnotetext{
${ }^{26}$ Boehmer, Postcolonial Poetics, 6, 184. Boehmer acknowledges her debt to Rita Felski in her opening pages, and though she never cites Latour directly (and actually claims in her final chapter that her approach to poetics does not "disavow critique" as such), the influence of Latour's ANT is discernible throughout her study, especially in its earlier chapters.

${ }^{27}$ Boehmer, Postcolonial Poetics, 5-9.

${ }^{28}$ Boehmer, Postcolonial Poetics, 9.

${ }^{29}$ Immanuel Kant, Anthropology from a Pragmatic Point of View, trans. Victor Lyle Dowdell (Edwardsville: Southern Illinois University Press, 1996), 42.
} 
intellectual producers whose labor has repeatedly failed to affect sought-after social change." ${ }^{30}$ As I conclude through my reading of Vásquez's novel, to stay with Latour is in the end to consign ourselves fully to the fate of capitalist realism and, more particularly, our current neoliberal dispensation.

Simply put, I see the post-critique critique of critique that Latour's work has inspired as an opportunity to reconsider the value of the kinds of critical and creative reading practices that Marshall Berman-writing in 1982 on the cusp of the neoliberal era, with its catastrophic consequences for higher education in general and the humanities in particular-saw not as opposed but as instrumental to a properly anti-capitalist politics. ${ }^{31}$ Although we should be cautious of subscribing to a metaphysics that views nonhuman objects as effective actants in order to satiate a long-held postcolonial interest in some inherent "agency" or "resistance" of literary texts, Latour's intervention should nevertheless alert us to some of the underlying and often unsaid designs of both postcolonial and world literary criticism-most notable among which is the desire to claim that literature has the ability to "make worlds." ${ }^{32}$ At a time when postcolonial and other forms of politicized world literary criticism are inclining toward posthumanist and even explicitly antihumanist methodologies, I argue that the work of Marxist humanist critics like Berman provides a model for a structural critique that does not inhibit our close readings, but rather opens them up. ${ }^{33}$ Although I am not convinced that it is in the one-to-one mapping of literary texts onto a system

${ }^{30}$ R. H. Lossin, "Neoliberalism for Polite Company: Bruno Latour's Pseudo-Materialist Coup," Salvage \#7: Towards the Proletarocene (2019): 131-55, esp. 133. Lossin's observation is not actually made of postcolonial and world literary critics, but I believe it is relevant to them, insofar as I myself-one such critic-recognize how politically tempting Latour's utter disavowal of a separation between text and world at first appears.

${ }^{31}$ The WReC worry a great deal about the complicity of various critical stances with the current neoliberal regime and its endemic marketization of higher education, and they don't pull their punches. Their fiery dismissal of Wai Chee Dimock's Through Other Continents as a "New Ageinfluenced eco-spirituality [that] mirrors neoliberal attacks on statal forms of regional self-determination in the "third world"' is one such example. See WReC, Combined and Uneven Development, 4546. More recently, two WReC members, Sharae Deckard and Stephen Shapiro, have doubled-down on the idea that a methodological offensive is an effective way to combat institutional neoliberalization in the introduction to their edited collection, World Literature, Neoliberalism, and the Culture of Discontent (Cham, Switzerland: Palgrave Macmillan, 2019), 21. For a thorough overview of the impact of marketization on the humanities in general and literary studies in particular, see Paul Jay, The Humanities "Crisis" and the Future of Literary Studies (New York: Palgrave MacMillan, 2014).

${ }^{32}$ For example, Cheah, What Is a World?.

${ }^{33}$ Carolyn Lesjak's self-confessedly "counterintuitive" contention that it is "an antihumanist, revitalised Marxism [that] offers the way forward for humanist study, given how irreducibly bound to the economy the humanities are today" is one of the more sophisticated and self-conscious examples of this antihumanist turn. See Carolyn Lesjak, "Reading Dialectically," Criticism 55.2 (2013): 233-77, esp. 238. In other places, antihumanism is used variously to decry a depoliticizing liberal universalism, the failure of rights-based politics, and neoliberal managerialism, to name only a few examples. See, for example, Deckard and Shapiro, eds., World Literature, Neoliberalism, and the Culture of Discontent. Though I don't have space to go into this in more depth here, what is too often missed in these dismissals is the centrality of a reconstructed Marxist humanism to twentieth-century decolonial writers, from Aimé Cesaire to Frantz Fanon-writers to whom postcolonial and indeed world literary studies owe a great deal. Indeed, although I focus on Berman here, I would situate him within a roster 
-world or otherwise-that the future of a radical literary studies resides, clearly an outright Latourian disavowal of capitalist modernity is an error as well. Instead, and following Berman's example in All That Is Solid, I argue that it is by turning up the volume on literary texts themselves-texts that we as critics read and teach day to day-that we might get a firmer grip on the "melting" effects of our neoliberal world, as well as the histories of imperialism and colonialism out of which it has grown.

\section{All That Is Solid Has Volume}

Published in Spanish in 2011, The Sound of Things Falling is Juan Gabriel Vásquez's fifth novel, and his third to be translated into English. It won the Alfaguara Novel Prize, the Dublin Literary Award, and English PEN Award, among others, cementing Vásquez's international reputation. Though beginning in Bogotá in the late 1990s, the novel incrementally reaches back into Colombia's twentieth-century history: rather than progressing forward, the plot spirals downward, an implosive structure captured in the "sound" of its title. This eponymous sound does not describe a climactic explosion-it is not the sound of things landing-but rather a subtler "whoosh" that melts into air. This is not a novel with a satisfying conclusion, and Antonio, our first person narrator, suffers from impotence for much of the book. ${ }^{34}$ The Sound of Things Falling therefore avoids the teleology of realist narrative, resembling instead the nested structure of a proto-modernist text like Joseph Conrad's Heart of Darkness (1899), a point to which I will return below. ${ }^{35}$

As readers, we do not see the novel's most important event: in the first chapter, American Airlines Flight 965, making the journey from Florida to Colombia, crashes into the hard rock face of the Andes, killing everyone on board-a real, historical incident that occurred on December 20, 1995. Instead, we only hear news of this event on the radio, partly because our narrator Antonio is understandably distracted by the ultrasound scan of his first child:

of other late-twentieth-century humanist critics, among them Edward Said, Stuart Hall, and bell hooks, all of whom are influenced by Fanon and other leading anticolonial humanists.

${ }^{34}$ Antonio's inability to get it "up, up, up" thus reflects the larger movement of the plot: at one point his partner, Aura, even purchases a vibrator in an attempt to revive their sex life, but all Antonio can do is "drop" it on the coffee table, where it "bounce[s] slightly" with a quiet thud (101). Juan Gabriel Vásquez, The Sound of Things Falling, trans. Anne McLean (London: Bloomsbury, 2013), 101. Following page references to the novel will be made in brackets after the quotation.

${ }^{35}$ Vásquez's is also clearly responding and contributing to South American detective fiction, a rich genre that includes writers such as Gabriel Garcia Márquez, Mario Vargas Llosa, and Roberto Bolaño, among many others. There are several excellent chapters addressing different aspects of this trend in Nels Pearson and Marc Singer, eds., Detective Fiction in a Postcolonial and Transnational World (Burlington: Ashgate Publishing Company, 2009). Michael Wood explicitly explores narco fiction as world literature in his chapter, "After Such Knowledge: The Politics of Detection in the Narconovelas of Elmer Mendoza," in Crime Fiction as World Literature, eds. Louise Nilsson, David Damrosch, and Theo D'haen (London and New York: Bloomsbury, 2017), 23-32. 
I regretted the accident, felt all the sympathy I'm capable of ... But it was an ephemeral and distracted sympathy, and I'm sure it had died out by the time we entered the narrow cubicle where Aura, lying down and half undressed, and I, standing by the screen, received the news that our little girl (Aura was magically sure it was a girl), who at that moment measured 7 millimetres, was in perfect health. (35)

In this early scene, the ultrasound of one event drowns out the falling sound of another-even Antonio's partner's name, "Aura," almost reads as "aural." The "real-life" plane crash initially appears as background noise, or a "reality effect" that adds texture to the novel's world. This is what Barthes calls, in a lesserknown essay, the "rustle of language," or "the noise of what is working well." 36 For Barthes, realism turns language into a window through which we view the world: in our immersion, we do not "hear" it. However, unlike Flaubert's barometer-a device not only designed to measure atmospheric pressure, but also to create novelistic atmosphere-the sound of the ostensibly inconsequential plane crash soon becomes far louder than a rustle. As the narrative proceeds, what at first appears as little more than a reality effect soon transforms into a Latourian "actant" that effects reality by determining the rest of the novel's plot. By aligning Barthes's extended sound metaphors with his own, Vásquez purposefully begins to confuse objects with subjects and representation with action, hinting at the Latourian metaphysics that shapes his novel's diegetic world.

It is impossible to understate the extent to which things fall and make a sound throughout this novel: in almost every paragraph, something drops to the ground, with the effect that we soon become alert to the novel's background noise as something symbolically and affectively meaningful. It is as though the novel itself were Flaubert's barometer, not simply measuring the atmosphere of a "real" world beyond it, but actively "effecting" or creating that atmosphere, too. Not only affecting, but effecting: atmospheric changes read as evocative metaphors for any number of things-Colombian history, cocaine addiction, uneven development, patriarchal impotence-but they are also brutally literal (actual planes fall out of the sky). In this novel, all sounds-which we should remember, for Kant, collapsed the split between abstract concepts and the material world-are made by physical "things" as they fall, thus rendering symbolic or metaphysical concepts as themselves physical actors in the world. Vásquez transforms his metaphors into world-making actants, and in so doing purposefully blurs the division between signifier and signified, text and world.

By the novel's second chapter, the volume of the plane crash drowns out the ultrasound of Antonio's new daughter. Antonio, now preoccupied by the circumstances of Flight 965, ignores Aura-he literally does not hear her-when she asks him whether he "wants to know how much [the baby] weighs" (62). Throughout, Vásquez puns on the word volume, or volumen, which signifies both a loud sound and a heavy mass, a weight that would drag something out of the

\footnotetext{
${ }^{36}$ Roland Barthes, "The Reality Effect" and "The Rustle of Language," in The Rustle of Language, trans. Richard Howard (Berkeley: University of California Press, 1989), 76-79, 141-48, esp. 76-77.
} 
sky. It is the volume of the crash-louder than the eventual birth of his childthat consequences the rest of the novel's plot and also Antonio's life, the falling plane eventually leading to the breakup of his new family. In the novel's final scene, Antonio returns home to find that Aura has left him and taken their daughter with her, leaving only a voice recording on the answer machine: "Forgive me, Antonio, but I can't do it any longer, and it's not fair on our little girl" (296). Listening to her message, Antonio finds he cannot "get enough air," his "self-sabotaging alveoli refusing to receive the oxygen" (296). The book concludes with the sound of things failing, Antonio's family life falling apart, while the atmospheric pressure suffocates our protagonist in a city world famous for its dizzyingly high altitude.

Aura's voice recording is doubly significant when we take the novel's most important (and nonhuman) actant into account. Antonio's obsession with Flight 965 takes hold when he hears the black box recording of the crash, or its aural representation. A cassette of this recording is retrieved by Ricardo Laverde, a retired pilot and the novel's other central protagonist, and it is played no fewer than three times across the novel's six chapters, in real time; that is, we see or hear characters listening to it in real time and witness their responses. This black box recording-"la caja negra"-is therefore in fact no mere representation, instead cycling through the novel's diegetic world and wreaking havoc as it goes. The black box is both literal and metaphoric-or more precisely, and after Latour, it refuses the distinction between those two qualities, operating on a metaphysical understanding of metaphors, concepts, and physical things as equally active, world-making actants. As I've discussed, Latour uses the term black box to describe concepts or statements that are treated as incontrovertible facts, but were not always accepted as such. ${ }^{37}$ According to Latour, modernity itself is a black box, a series of conflicts and alliances calcified into a single concept that, in most academic papers, we take for granted, but that can in fact be opened and disassembled. As Graham Harman explains, when a concept becomes a black box we can "forget the massive network of alliances of which it is composed, as long as it functions smoothly." 38

Allegorically pursuing Latour's own opening of the black box of modernity, the black box in Vásquez's novel is opened and unpacked, a process epitomized nowhere more emphatically than in Antonio's reflections on black boxes themselves:

With time I have found out more about black boxes. I know, for example, that they're not black, but orange. I know that aeroplanes carry them in the empennage-the structure we profane people call the tail-because they have a better chance of surviving an accident there. And yes, I know that black boxes survive: they can withstand 2,250 kilograms of pressure and temperatures of 1,100 degrees Celsius... . I don't think anyone considers that a black box might have other fates, to fall into hands that were not part of its

\footnotetext{
${ }^{37}$ Latour, Science in Action, 43.

${ }^{38}$ Harman, Prince of Networks, 34.
} 
plan. However, that's what happened to me with Flight 965's black box, which, having survived the accident, was magically transformed into a black cassette with an orange label and went through two owners before coming to form part of my memories. And that's how this apparatus, invented to be the electronic memory of planes, has ended up turning into a definitive part of my memory. (89)

Antonio has listened to the black box recording, but he has also found out a series of facts about black boxes, unraveling the thing itself in typically Latourian fashion to trace the alliances that went into its composition. The black box, which is actually orange, becomes a "black cassette with an orange label," and the "electric memory of planes" becomes "a definitive part of [Antonio's] memory"a memory that comprises, as our narrator often insists, the novel we are reading itself. This is, in a Latourian account, the sound of things falling: a black box is an object that, once its components are taken for granted, becomes a thing, to use Latour's precise terminology. ${ }^{39}$ Opening it up, however, we discover that this thing is not only a combination of physical objects (nuts, bolts, metal, tape), though it is those. Just as "literally," it is also has metaphorical parts: Antonio's memory, Colombian history, Vásquez's novel. In The Sound of Things Falling, as in Latour's metaphysical universe, affect is effect, and reality has symbolic meaning: the novel does not weave these two planes back together because, from a "nonmodern" perspective, they were never divided in the first place.

Throughout The Sound of Things Falling, the black box recording does not therefore merely reflect or record the world; it also pushes it forward and makes things happen. Antonio, who is a lecturer in law at the University of Bogotá, meets Laverde by chance in a bar in the Colombian capital in the mid-1990s. In the first of a series of nested revelations that-much like the plane from Miami to Bogotá-never arrive anywhere, it transpires that Laverde's wife, Elena, was on board Flight 965 and died in the crash. Laverde therefore retrieves the black box recording to listen to the sound of his wife's death..$^{40}$ Antonio knows a café owner who will lend Laverde a cassette player and takes him there, watching Laverde as he listens to the tape through a pair of headphones. ${ }^{41}$ Antonio does

\footnotetext{
${ }^{39}$ Latour, Science in Action, 91.

${ }^{40}$ It is never explained how Laverde managed to get hold of the black box recording in the novel. However, the journalist Frank Bajak documented at the time of the real plane crash in 1996 how a number of "outlaw salvagers" descended on the remnants of Flight 965 and extracted "bogus parts" for unofficial resale, so it really is possible that Laverde bought the black box on the black market. See Frank Bajak, "Black Market in Bogus Parts Poses Peril to Airline Passengers," Los Angeles Times, December 15, 1996 (https://www.latimes.com/archives/la-xpm-1996-12-15-mn-9234-story.html).

${ }^{41}$ We are, therefore, led to presume that Laverde does not have a cassette player at home, a seemingly mundane yet again active reality effect that makes the novel's whole plot possible. Furthermore, it alerts us to recent historiographic arguments that Colombia's economic growth has for centuries been inhibited by a failure to "embrace technological progress," especially when compared with its Latin American neighbors. See Ivan Luzardo-Luna, Colombia's Slow Economic Growth: From the Nineteenth to the Twenty-First Century (Cham, Switzerland: Palgrave MacMillan, 2019), for his argument that Colombia 'missed three technological waves of the last three centuries: steam, mass production, and Information and Communication Technology', esp. 1-10.
} 
not hear the recording himself on this first listen: instead, he listens to a different recording that lies coincidentally to hand-a reading of the celebrated nineteenth-century Colombian poet José Asunción Silva's posthumously published poem, "Nocturne III" (1908). While listening to the poem, Antonio watches Laverde who, hearing the recording of his wife's death, breaks down and weeps.

In this scene, we watch with Antonio as Laverde hears something-we cannot hear it, but we see it physically affecting its listener. Instead, we are treated only to Antonio's inner monologue interspersed with fragments of Silvio's poem, the first two lines of which-"Una noche,/ una noche toda llena de perfumes, de murmullos y de música de alas"-both describe and, in their poetic beat, mark out the physical affect of fireflies' fluttering wings. ${ }^{42}$ When Antonio eventually listens to the tape himself, he reconstructs the scene in such an absurd level of detail that it is, again, not a reflection of reality, but more accurately, its affectation. Antonio intends not to accurately represent the event documented in the recording, but rather to impress upon the reader an affective reality in which all objects, both human and nonhuman, are actors: "I've imagined that moment a thousand times, a thousand times I've reconstructed it like a stage designer constructs a scene, and I've filled it with speculations about everything" (84). As our narrator concedes, the recording has been made real by his own retrospective addition of numerous, atmospheric reality effects.

Moments after Antonio and Laverde leave the café, in the first months of 1996 and, as the novel tells us, just two years "after Pablo Escobar was killed" (28-29), two assassins drive by on a motorbike, murdering Laverde and wounding Antonio. This moment concludes the novel's first chapter:

I saw the faceless heads looking at us and the pistol pointed towards us as naturally as a metal prosthesis, and saw two shots, and heard the explosions and felt the sudden tremor in the air. I remember having raised my arm to protect myself just before feeling the sudden weight of my body. My legs no longer held me up. Laverde fell to the ground and I fell with him, two bodies falling without a sound, and people started to shout and a continuous buzzing appeared in my ears.... A short while later I lost consciousness, but the last image that I have is still quite clear in my memory: it's that of my body lifted into the air and the effort of the men who put me into the back of the truck, who put me down beside Laverde like one shadow next to another, leaving on the bodywork a bloodstain, which at that hour, with so little light, was as black as the night sky. (46-47)

Light travels faster than sound in this scene: Antonio "saw two shots," and only then hears "the explosions," and only then feels "the sudden tremor in the air" (46). One volume transmogrifies into another, the explosive action of the shot moving into the "sudden weight" of Antonio's body, which like all of Vásquez's things falls "to the ground"-only this time "without a sound" (46). Peculiarly,

\footnotetext{
${ }^{42}$ José Asunción Silva, Obra Completa (Mexico City: Consejo Nacional Para La Cultura Y Las Artes, 1992), 20-21. There may also be a surreptitious reference here to the falling-indeed, cascadingright-hand arpeggios of Chopin's Nocturne in B major, Op. 9, No. 3.
} 
although Antonio claims to remember a "last image," he describes something more like an action sequence: his body, having fallen, is lifted up again, reduced to little more than a "shadow," despite there being "so little light" (46-47). Laverde dies in this sentence, and though Antonio survives, the actual substance of their bodies melts into nothing more than "a bloodstain" on the "bodywork" of the truck (47).

This is a universe of Latourian metaphysics: in his fiction, Vásquez does not construct accurate representations of bodies, as though he were writing the equivalent of a photographic image. As Latour would argue, a photograph is itself a black box, a thing we tend to accept as "unquestionable data," even as we also insist-admittedly with some questionable paradox-that it is only a copy or representation, not "reality" itself. Against this, Vásquez writes bodies as wholly relational objects that become more real through their networked alliances with other things. They are linked together in an endless chain of translations that move from the text within the text to the text's narrator and finally from its narrator to the reader themselves: "Nothing exists but actants, and all of them are utterly concrete." 43

Although the details of Laverde's life are not yet revealed at this point in the narrative, Vásquez's mention of Escobar alerts readers to the possible motive behind the assassination: it is evident, though not yet evidenced, that Laverde's murder is related to Colombia's infamous narcotics industry. Such attacks became frighteningly commonplace during the reign of Escobar and his Medellín cartel, which conducted routine assassinations from the early 1980s through to $1993 .{ }^{44}$ One of the most shocking of these occurred in November 1989, when a planted bomb blew Avianca Airlines Flight 203 out of the air in an attempt to kill then presidential candidate César Gaviria. Although Gaviria turned out not to be on board, 107 innocent passengers and crew were killed. ${ }^{45}$ Of course, for Vásquez, the already palpable parallels between the "real" assassination attempt on Gaviria and his fictionalization of the equally "real" American Airlines Flight 965 are coupled, just like everything else in the novel, as interrelated, consequential actants. ${ }^{46}$ Even narcotics themselves, as Hermann Herlinghaus points out, are typically Latourian "quasi-objects," enmeshing nature and society, the human and the nonhuman, together. ${ }^{47}$ The more we read, the deeper Antonio

\footnotetext{
${ }^{43}$ Harman, Prince of Networks, 16.

${ }^{44}$ See Michael J. LaRosa and Germán R. Mejía, Colombia: A Concise Contemporary History, 2nd. ed. (London and New York: Rowman \& Littlefield, 2017), esp. 98-100.

${ }^{45}$ Joseph Fabry, et al., "Turning Points in the Colombian Conflict, 1960s-,1990s," The Colombia Reader: History, Culture, Politics, eds. Ann Farnsworth-Alvear et al. (Durham, NC, and London: Duke University Press, 2017), 426-33, esp. 427.

${ }^{46}$ Antonio draws a direct connection between Gaviria and Laverde when Flight 203 falls on the same piece of land as another plane, crashed by a different character (also named César, though a pilot, not a politician) earlier in the book. Given that the reader should by now be in on the game of his interconnected ANT universe, Antonio at this point sardonically remarks: "But I don't think this coincidence means anything" (262).

${ }^{47}$ Hermann Herlinghaus, Narcoepics: A Global Aesthetics of Sobriety (New York and London: Bloomsbury, 2013), 2, 6-7.
} 
digs, the more the black box is unpacked, and the more we see that everything becomes more "real" through its alliance with other things. Against Barthes's barometer, which creates a reality effect by being utterly ineffective, having no consequential relationship with anything else, Vásquez's world becomes effectively "real" because all of its quasi-objects are physically meaningful, connected together as actors in a network.

Forever wounded by the attack and no longer able to "get it up," Antonio instead descends into Laverde's life history to try and make sense of this traumatic event. He learns that in the late 1960s Laverde had made a small fortune by regularly flying shipments of cocaine to Nassau in the Bahamas. Then, on a last risky trip to Florida (the journey that leads to his wife's death, though made in reverse), Laverde was caught, arrested, and imprisoned for almost twenty years. His wife, Elena, an American by birth, returns to the United States, where she waits for Laverde's release: Flight 965 is therefore the flight that, had it not crashed into the Andes, would have at last reunited them both.

This is what Antonio hears when he eventually listens to the black box recording of the plane crash firsthand:

There is a faltering scream, or something that sounds like a scream. There is a sound that I cannot or have never been able to identify: a sound that's not human or is more than human, the sound of lives being extinguished but also the sound of material things breaking. It's the sound of things falling from on high, an interrupted and somehow also eternal sound, a sound that didn't ever end, that kept ringing in my head from that very afternoon and still shows no sign of wanting to leave it, that is forever suspended in my memory, hanging in it like a towel on a hook. (87-88)

The sound of things falling, recorded on the black box, is neither human nor nonhuman, subject nor object: it is, like all the other things in the novel, both natural and social, physical and metaphoric-a Latourian "quasi-object." For Hyeryung Hwang, in Vásquez's novel "the private existence of individuals is intertwined with the public history of the country... . The history of an individual is told through public events in Colombia, which shows how individuals are already born in the shared fate of the community." 48 Following Latour, a slight error lies in that word intertwined, which suggests the different actants-private individual, public history, shared community-were somehow once separate, brought back together in the novel's writing. For Latour, and seemingly for Vásquez too, objects are not already born into relationships, but are rather born through their relationships with other human and nonhuman things, and now these things have related with us readers too. Lifting the word affectively (and effectively) from the page and into the "real" world, the "eternal sound" of the crash continues to ring in the reader's head, "hanging in it like a towel on a hook" long after they have put the book down.

\footnotetext{
${ }^{48}$ Hyeryung Hwang, “After Magic: Juan Gabriel Vásquez's The Sound of Things Falling and Narco Realism,” The Midwest Quarterly 61.2 (2020)” 186-203, esp. 195-96.
} 


\section{All That Is Solid Falls from the Sky}

Vásquez's network of interrelated narrative details extend further backward in history as the novel unfolds. With each new revelation, more actors are uncovered, and the past deepens and shifts. The whole network of relationships is therefore visible only from the vantage point of the final chapter, and even then there are more "real-world" actants to discover, as a little research into the historical events that are fictionalized in the novel quickly reveals. The novel therefore imitates Latour's "retroactive theory of time," where interpretation becomes not a hermeneutics of suspicion that reveals some underlying a priori truth, but a process of production that re-creates the world instead. ${ }^{49}$ Just as, in a Latourian account, the act of reading by postcolonial critics would be said to reactivate the histories and perhaps even the resistance embedded in literary texts, Antonio's (highly subjective) research into Laverde's life unfolds a retroactive narrative of Colombian history: fictionalizing historical events does not so much reflect the past as it re-creates the events as active agents again in the present. The Sound of Things Falling begins near its own chronological end, returns to a historical event, then loops back around to the present, before reaching further back into history, then cycling back to the present again, and so on as the novel proceeds. The narrative loops the thread of the past into the fabric of the present, which thickens with historic moments that are not "past" at all, but still very "real," reactivated through their "alliance" first with Antonio and then us.

In this winding chronology, all actors are engaged in what Latour calls a "circulating reference," producing a nonlinear and nonmodern conception of time. As Latour writes:

We do have a future and a past, but the future takes the form of a circle expanding in all directions, and the past is not surpassed but revisited, repeated, surrounded, protected, recombined, reinterpreted and reshuffled. Elements that appear remote if we follow the spiral may turn out to be quite nearby if we compare loops... . In such a framework, our actions are recognised at last as polytemporal..$^{50}$

The mistake of the moderns, argues Latour, has been to try and mend the "gap between words and world" without accounting "for the entire chain, as if they had tried to understand how a lamp and a switch could 'correspond' to each other after cutting the wire." ${ }^{51}$ In a world where things become real through their direct relationship with other things, Antonio's rediscovery of the details of Laverde's past, no matter how unverifiable they may be, makes those things more

\footnotetext{
${ }^{49}$ Harman, Prince of Networks, 83-84. Latour uses the example of the French biologist Louis Pasteur, who "reinterpreted the past practices of fermentation as fumbling around in the dark with entities against which one could now protect oneself." The result, he continues, "was to produce in 1864 a new version of the years 1863,1862, 1861, which now included a new element: 'microbes fought unwittingly by faulty and haphazard practices."' See Bruno Latour, Pandora's Hope: Essays on the Reality of Science Studies (Cambridge, MA: Harvard University Press, 1999), 169.

${ }^{50}$ Latour, We Have Never Been Modern, 75.

${ }^{51}$ Latour, Pandora's Hope, 73.
} 
real, not less. In this metaphysical universe, the repetitive sound of so many things falling-far too many to pass as Barthesian reality effects-does not in fact detract from the novel's creation of a realistic world, but strengthens it instead. The novel is nonmodern in this reading, proceeding on the assumption that word and world are not separate, but in fact one and the same, words working as actors in a network with other things.

This at first appears to accord with Vásquez's own worldview. He has on several occasions spoken of his struggle to write about his native Colombia, reflecting that he only came to do so when he shook off his early training in the realism of the Hemingwayian tradition, which-as he saw it-condemned writers to write about only what they knew. As he comments:

It took me some years and some novels that I read, and the discovery of some authors-Philip Roth was one of them, Joseph Conrad was the most important of them all-to discover that not understanding my country was precisely the best reason to write about it. The idea that literature is a discovery, an act of inquisition, you ask questions. You don't write because you know, you write in order to know, in order to find out. At that moment I found out that I'm allowed to write about my country, about Colombia. ${ }^{52}$

Vásquez's conception of literary worlds, read through Latour, certainly feels nonmodern. His aim is not to represent the world, but to write it into being: there are important colonial connotations carried over here, certainly, but Vásquez is deeply attuned to this history, as his careful word choices ("discovery," "inquisition") suggest. Indeed, Vásquez wants to seize the influence of a writer like Conrad, who may not have accurately represented Africa or South America, but-as any postcolonial critic will tell you-undeniably produced powerful, world-making ideas about them that endure to this day. Thus, Vásquez indicatively uses the word build, a typically Latourian verb, rather than write when describing his craft. He builds reality, and he thinks of literature-both the acts of reading and writing-as accomplices in that productive process. For Vásquez, novels don't represent the world; rather, we understand "the world through novels": novels and the world are not separate, or divided, but mutually constituting actors working in alliance to make each other more real. ${ }^{53}$

Antonio himself "acts out" this approach to novel writing (and reading), not telling the story, but rather discovering it, a process in which he also implicates us as readers. He is at first a bystander, himself "a reader," an academic lecturer in law: when he encounters Laverde, he is simply a man in a bar. It is only when Antonio acts that the details of Laverde's life take shape and become real, impacting upon Antonio's life in turn. The result is a spiraling sequence, a process of circulating reference that makes irrelevant events suddenly consequential. Antonio moves through a world that he is not only describing, but a world that

\footnotetext{
${ }^{52}$ Jorge Ruffinelli, "Juan Gabriel Vásquez: History, Memory and the Novel," Nuevo Texto Crítico 2627.49-50 (2013/2014): 151-63, esp. 154. See also Jess Row, "A Conversation with Juan Gabriel Vásquez and Jess Row," Review: Literature and Arts of the Americas 48.1 (2015), 131-38, esp. 134.

${ }^{53}$ Ruffinelli, "Juan Gabriel Vásquez," 151.
} 
his descriptions effect. He is not only a reader, nor even a narrator, but also an actor as well, and as we come into contact with Antonio, we readers become actors too: following Latour, by reading the novel we form an alliance with it and make it more real in the world.

Most astonishing of all is Vásquez's solidification of Latour's metaphysical concepts into the physics of his novelistic world. Like Latour, Vásquez appears to see the two-metaphysics and physics, the metaphoric and the literal-as indivisible spheres. The sound of the thing falling is the thing falling. The black box, Latour's conceptual word for an "object become thing," is the solid thing at the center of the novel. For Latour, history is a circulating referent, while in Vásquez's novel all things circle as they fall: the plot, Antonio's life, the airplanes themselves-all that is solid spirals down to earth and, in what is surely a tonguein-cheek reference to the ur-text of postcolonial studies, all "things fall apart." ${ }^{4}$ Literary critics need no longer grapple with an a priori conception of the world, be it the world-system or even the poetic structures of the text: instead, the text is an actor in a network with us, and through our alliance we build the real world.

\section{All That Is Solid Makes a Sound}

So far, so good: Vásquez presents his novel as self-reflexively Latourian, making the case for its own affective and effective agency as a literary text moving through the world. This is surely the methodology that postcolonial and world literary critics have long sought out-a metaphysical model that theorizes the impact of literary texts as world-making actants.

And yet, it still feels important to ask: Is it really possible to have a metaphysics while also claiming that there is no nonphysical essence whatsoever? ${ }^{55}$ Has Barthes really melted into air, ridiculed for his "Empire of Signs," or are we actually back where we started? Is this not in fact the death of the author all over again-the death, that is, of a godlike Latour, now the sole and only occupant of the metaphysical realm? Berman's work on Faust can help us here. For while Latour and Vásquez both suggest a potentially democratic equality between text and reader (and every object in between), they themselves, as authors, disappear. As R. H. Lossin remarks, "Latour wants everyone to ignore the forest for the trees because he is the forest. Even if we have never been modern, Latour certainly is." ${ }^{56}$ In this reading, Latour is in fact Goethe's Faust, the modernist par excellence, an author who has rebuilt the world in his image. We may all be actors in a network, becoming more real through our alliances with one another and with literary texts, but there remains a totalitarian author figure who can see the whole network. We can follow the conceptual rhymes of Latourian

\footnotetext{
${ }^{54}$ Chinua Achebe, Things Fall Apart (London: Penguin Modern Classics, 2001).

${ }^{55}$ Even Harman, Latour's most vocal advocate, concedes the impossibility of a purely physical metaphysics. As he writes: "It may be (as I myself hold) that metaphysics demands a distinction between the inner reality of a thing and its relations with other entities." Harman, Prince of Networks, 75.

${ }^{56}$ Lossin, "Neoliberalism for Polite Company," 140.
} 
nonmodernism forever, but with no structural critique this will only lead us along veins in an unending network-meanwhile, no action ever takes place.

While Latour's ANT might metaphysically resolve attempts to activate literature in the world, we should therefore take care to ask what that "world" actually looks like. Vásquez's novel is useful again here, for after five chapters of subjection to the metaphysics of a Latourian universe, Antonio has a pretty good feel for it. This is how the novel's final chapter begins:

Disillusion comes sooner or later, but it always comes, it doesn't miss an appointment, it never has. When it arrives we receive it without too much surprise, for no one who lives long enough can be surprised to find their life has been moulded by distant events, by other people's wills, with little or no participation from their own decisions. Those long processes that end up running into our life-sometimes to give it the shove it needed, sometimes to blow to smithereens our most splendid plans-tend to be hidden like subterranean currents, like tiny shifts of tectonic plates, and when the earthquake finally comes we invoke the words we've learned to calm ourselves, accident, fluke, and sometimes fate. Right now there is a chain of circumstances, of guilty mistakes or lucky decisions, whose consequences await me around the corner; and even though I know it, although I have the uncomfortable certainty that those things are happening and will affect me, there is no way I can anticipate them. Struggling against their effects is all I can do: repair the damage, take best advantage of the benefits. We know it, we know it very well; nevertheless it's always somewhat dreadful when someone reveals to us the chain that has turned us into what we are, it's always disconcerting to discover, when it's another person who brings us the revelation, the slight or complete lack of control we have over our own experience. $(243)^{57}$

So much for Latour's democracy of objects..$^{58}$ In this world devoid of structural concepts like "capitalism," "imperialism," "finance," "society," "government," or even "the nation-state," "distant events"-settler colonialism in the Americas, political decisions in Washington DC, neoliberalism's unfettering of economic markets-become "accidents" or "flukes," just another action in a string of "chain" reactions on which we can never get a solid grip, as Berman had hoped.

${ }^{57}$ This is the passage, perhaps more than any other, that cements my conviction that Vásquez is intentionally and directly engaging with Latour's work in The Sound of Things Falling. The tell, I think, is the prevalence of geophysical metaphors-"tiny shifts in tectonic plates" and "subterranean currents"-which are such a staple of Latour's rhetoric.

58 To be fair to Latour, this "ontologization of politics" appears to be more prevalent in his earlier work, while it softens in his later writings. See Graham Harman, Bruno Latour: Reassembling the Political (London: Pluto Press, 2014), 14. Nevertheless, the implicit suggestion that ontologies cannot or should not be politicized, a claim Harman makes in his defense of Latour, risks erasing much that is of value in recent decolonial movements and studies. For just two examples among many, see Julietta Singh, Unthinking Mastery: Dehumanism and Decolonial Entanglements (Durham, NC, and London: Duke University Press, 2018), and Marisol de la Cadena and Mario Blaser, eds., A World of Many Worlds (Durham, NC, and London: Duke University Press, 2018). 
Capitalism might be hard to overthrow, or imperialism difficult to contest, but it becomes even harder if those structural forces disappear from view. Nothing more than an actor in a horizontal network, Antonio has no race or class to become conscious of, or allies to affiliate with, no collective bodies to appeal to, democratically elect, seize control of, or overthrow-he lives, in effect, in a neoliberal world. ${ }^{59}$ Against this, it is only when we approach Vásquez's novel with the tools of structural critique that it becomes radically, self-reflexively modernist, in Berman's definition, exposing the Faustian drama of modernity and sounding out the full force of its historical violence. We must therefore turn to this brief reading before building to a better conclusion.

In his study of sound in literary modernism, Sam Halliday explores the sonic politics of Conrad's Heart of Darkness in some detail. ${ }^{60}$ As Halliday notes, in a preface to the 1902 edition of the novella, Conrad speaks of his purposeful emphasis on the text's "tonality," a technique with which he hoped to create a "continued vibration that ... would hang in the air and dwell on the ear after the last note had been struck." ${ }^{61}$ Within the novella itself, Marlowe repeatedly emphasizes "the silence of the [African] land," describing it as "mute with an air of whispering." ${ }^{2}$ As Halliday concludes, Africa is the sign of "all that is 'primitive,' 'savage' and above all, primordial": "Primordiality ... in Marlow's narration, is silence; conversely, sound becomes the sign of historicity." ${ }^{63}$ Sound is not in fact exempt from modernity's Great Divide, as Kant had thought, but rather its most violent reinscription. The horror of Kurtz is that he is only ever shown to be "discoursing," never "doing" anything, an inflection that subtly absolves him of the colonial violence he has wrought. ${ }^{64}$ Kurtz is, in essence, Marlowe's Faust-clearly, the name of Conrad's narrator is not incidentally chosen. He is a transcendent, disembodied, authorial being who, much like Latour, is "very little more than a voice," using the cloak of audibility to create a metaphysical world in his own image. This, of course, is also the accusation that Chinua Achebe leveled at Conrad himself. To paraphrase Achebe's critique, the physics of colonialism in Africa are reduced to nothing more than the metaphysics of the colonial mind. ${ }^{65}$

We would do well to remember what was inside Vásquez's black box, for it resonates with Conrad's words: "The sound of things falling from on high, an interrupted and somehow also eternal sound, a sound that didn't ever end" (87).

\footnotetext{
${ }^{59}$ See Lossin, "Neoliberalism for Polite Company," 133, for a succinct description of the similarities between neoliberalism and Latourian metaphysics.

${ }^{60}$ Sam Halliday, Sonic Modernity: Representing Sound in Literature, Culture, and the Arts (Edinburgh: Edinburgh University Press, 2013), 30-43.

${ }^{61}$ Halliday, Sonic Modernity, 33. Halliday cites Conrad's "Preface" to Youth: A Narrative, and Two Other Stories (London: J. M. Dent, 1937), 71-74, esp. 73.

${ }^{62}$ Joseph Conrad, Heart of Darkness, and Other Tales (Oxford: Oxford University Press, 1990), 150, 170.

${ }^{63}$ Halliday, Sonic Modernity, 34-35.

${ }^{64}$ Conrad, Heart of Darkness, and Other Tales, 203.

${ }^{65}$ As Achebe writes: "Africa as setting and backdrop which eliminates the African as human factor. Africa as a metaphysical battlefield devoid of all recognizable humanity, into which the wandering European enters at his peril." Chinua Achebe, "An Image of Africa," Research in African Literatures 9.1 Special Issue on Literary Criticism (1978): 1-15, esp. 9.
} 
The real horror, perhaps, has been our readerly distraction, our impulsive attempt to engage in the text's metaphysical games rather than accounting for the physical history of colonialism and imperialism. The above Latourian reading is so preoccupied by sounds in The Sound of Things Falling that it fails to "hear" the real actants who have remained silent but present throughout. For example, there is "the dark-skinned woman with the long black braid who floated like a phantom through [Laverde's] house cleaning and putting everything in order as she went" (216, my emphasis); and there are "the pre-Colombian pieces" that adorn Laverde's shelves, "a little man sitting cross-legged with an enormous phallus" (290). One character even points these premodern sculptures out to Antonio, but they remain ostensibly meaningless because they remain silent. And there is more: Laverde uses his narcotics income to build "a property marked by fences" in rural Colombia, labeling it in properly settler colonial fashion with a huge sign "etched and singed with the name of the property: Villa Elena" (224). He even hangs the sign from a "brick gate" by "two iron chains that looked like they'd been taken off a shipwreck," the physical yet silent things of Vásquez's novel bearing the traces of both the indigenous and African slavery that fueled Colombia's economy through the seventeenth, eighteenth, and nineteenth centuries. ${ }^{66}$

Importantly, these silent histories cannot be heard without the reintroduction of modernity. In a Latourian world, narcotics may be quasi-objects that dissolve metaphysical boundaries between subject and object, human and nonhuman. But if we reinsert modernity, narcotics become a physical commodity at the center of long histories of settler colonialism in the Americas. As the Cuban intellectual Fernando Ortiz described in 1940: "When Christopher Columbus stepped on American soil, for the first time in Guanahaní on October 12,1492 , the Indians of the island greeted him with an offertory rite, a gift of tobacco." ${ }^{67}$ The commodification of tobacco (eventually as cigarettes) and coca leaves (into cocaine), not to mention other narcotics including sugar and caffeine, has fueled the economics of Western modernity since its inception. ${ }^{68}$ Thus, by filling the volume of Laverde's "mule" aeroplane with vast quantities of cocaine, which he then flies to the Bahamas (Nassau, not Guanahaní, but geographically close by), Vásquez folds the twentieth-century history of US imperialism-manifested here in Nixon's "War on Drugs" (215) and the creation of the Drug Enforcement Agency in 1973 (224)-into a longer narrative of colonial modernity.

Cementing this reading, Laverde names his property after his American wife, Elena, who first arrives in Colombia with the US Peace Corps to administer aid through different forms of infrastructural development, including roads, sewers, and irrigation systems (she becomes increasingly frustrated by Colombia's "lack

\footnotetext{
${ }^{66}$ For a thorough overview of this early history, see María Cristina Navarette, Génesis y Desarrollo de la Esclavitud en Colombia, Siglos XVI y XVII (Ciudad Universitaria, Meléndez: Universidad del Valle, 2005).

${ }^{67}$ Fernando Ortiz, Cuban Counterpoint: Tobacco and Sugar, trans. Harriet de Onís (Durham, NC, and London: Duke University Press, 1995), 14-15.

${ }^{68}$ See Herlinghaus, Narcoepics, 6-9.
} 
of progress") (201). Laverde even uses "generous bribes" to help "electricity cables and water pipes arrive ... faster," though with limited success (223). And then, in April 1976, three years after the formation of the DEA, Colombia's rainy season turns into a "civil disaster" as the Miel River rises and decimates what little local infrastructures do exist (228). ${ }^{69}$ In this third and final fold, Vásquez further connects Western modernity to ecological devastation, the thunder of this background noise rumbling with structural meaning. As Berman observes in his reading of Goethe's Faust, the very last thing Faust hears before he dies is the "the sound of shovels" building his "great drainage canal." 70 But Laverde is not Faust: he has not made a deal with the devil, but only with one supplier in a long Latourian chain of suppliers; his drainage canals cannot keep the waters at bay; and he cannot be a subject, but only a disempowered object of the modernizing world.

\section{All That Is Solid Melts into Air}

Taking their fates together, Laverde and Antonio return us to Berman and his commitment to a modernism that enables people to "become subjects as well as objects of modernization, to get a grip on the modern world and make themselves at home in it"-to be authors of their own lives, we might say. ${ }^{71}$ Berman argues for "a broader and more inclusive idea of modernism than those generally found in scholarly books," insisting through his own praxis that literary textswhether those of Goethe, Marx, or Baudelaire-are as alive in the world as one of Robert Moses's highways. Against all the things that melt into air, close reading literary works becomes something solid, a concrete terrain on which to regroup. For Berman, the volume of the literary text can be as readily drowned out by an overdetermined a priori structure as it can by the absence of any structural critique at all: mediating between these scales, his modernist practice whittles down impactful processes like capitalism and imperialism to the scale of "human minds or souls," though without losing sight of their structural contours. ${ }^{72}$ As Marx embellishes in his original coinage: "All that is solid melts into air, all that is holy is profaned, and man is at last compelled to face with sober senses, his real

\footnotetext{
${ }^{69}$ I have been unable to confirm whether April 1976 really was a particularly bad rainy season in Colombia. However, it is perhaps worth noting that 1976 was also the year when the company Exxon (today ExxonMobile) signed a contract to develop the Cerrejón coal mine in Colombia-the largest coal mine in Latin America and the tenth largest in the world-with devastating consequences for local indigenous communities. See Oliver Balch, "Cerrejón Mine in Colombia: Can It Address Its Human Rights Risks?” The Guardian, July 25, 2013 (https://www.theguardian.com/sustainable-busi ness/cerrejon-mine-colombia-human-rights).

${ }^{70}$ Berman, All That Is Solid Melts into Air, 79. See also Goethe, Faust, 291.

${ }^{71}$ Berman, All That Is Solid Melts into Air, 5.

72 Berman, All That Is Solid Melts into Air, 131-32. Though I do not have space to unpack this further, I believe Berman's emphasis on a Marxist humanism is crucial here, staking out ground against both the antihumanism of some recent materialist critique and the posthumanism of Latour. I do concede the importance of Latour's work for, say, allowing us to think about the more-than-human scales of the Anthropocene, but again, I would refer readers back to All That Is Solid as well, which is remarkably conscious of ecological violence and ahead of its time in that regard.
} 
conditions of life, and his relations with his kind." ${ }^{33}$ In a world where modernity's narcotics dose us into disorientated neoliberal subjects, listening to a text-as Antonio himself tried to do-might be one way of sobering up.

Instead of Latour's pseudo-radical metaphysics or a prescriptive program of symptomatic critique, Berman's definition of modernist practice-admittedly with some geopolitical and geophysical update-might offer a more progressive template for reading postcolonial and world literature closely, creatively, and politically, in and against our own neoliberal present. As he writes in the preface written for the second edition of All That Is Solid in 1988:

[Modernism] creates conditions for dialogue among the past, the present and the future. It cuts across physical and social space, and reveals solidarities between great artists and ordinary people, and between residents of what we clumsily call the old, the New and the Third Worlds. It unites people across the bounds of ethnicity and nationality, of sex and class and race. It enlarges our vision of our own experience, shows us that there is more to our lives than we thought, gives our days a new resonance and depth. ${ }^{74}$

A "new resonance" indeed-this sound is no longer the ringing shovels of Faust's laborers, the lingering horror of Kurtz's disembodied voice, or the piercing crash of Flight 965 into the Andes. It is instead a modernist "melting" vision, one that Berman finds throughout Marx's works and that "pulls against the more 'solid' Marxian visions we know so well." ${ }^{75}$ Such a vision better emphasizes the creative volume of the postcolonial or world literary text in relation to structural critique, though without losing sight of the material violence of capitalist development, settler colonialism, and imperialism.

Latour is helpful insofar as he reminds us to attend to the literary text as an active force, one that connects to the world not of its own accord or through a priori concepts such as the world-system, but through its physical relationship with mediating actors, including readers, teachers, and critics. Though we can go some way with Latour, however, we also have to come back. Only when we do might we recognize the solid role that, as literary critics, we ourselves play within a larger structural movement, communicating the value of close reading as a political and politicized activity to our students, our allies, our interlocutors -yes, even our networks-though without reducing the text to activism in and of itself, or confusing our work with other (equally important) forms of structural analysis and direct action. This, it seems to me, describes the real physics of postcolonial and world literature under capitalist modernity: perhaps, following Vásquez's evocative example, and Berman's more expansive definition, we need to learn to be modernists again.

\footnotetext{
${ }^{73}$ Karl Marx and Friedrich Engels, The Communist Manifesto (London: Penguin, 2002), 223.

${ }^{74}$ Berman, All That Is Solid Melts into Air, 5.

${ }^{75}$ Berman, All That Is Solid Melts into Air, 89, my emphasis.
} 
Author biography. Dominic Davies is Senior Lecturer in English at City, University of London. He is the author of two monographs and the coeditor of three edited collections, along with several articles and book chapters broadly in the fields of colonial and postcolonial literature and culture. (Email: dominic.davies@city.ac.uk)

Cite this article: Davies, Dominic. 2022. "All That Is Solid Falls from the Sky: Modernity and the Volume of World Literature." The Cambridge Journal of Postcolonial Literary Inquiry 9, 1-25. https://doi. org/10.1017/pli.2021.33 